\title{
最早的中药辅料炮制品: 西汉海昏侯墓出土的木质漆 盒内样品鉴定与分析
}

彭华胜 ${ }^{1,2 \dagger}$, 徐长青 ${ }^{3 \dagger}$, 袁媛 $^{2 \dagger}$, 查良平 ${ }^{1}$, 陈焕文 ${ }^{4}$, 管理 ${ }^{3}$, 康利平 $^{2}$, 杨军 $^{3}$, 王亚君 ${ }^{2}$, 曹丽娟 ${ }^{5}$, 程京 ${ }^{6}$, 黄璐琦 $^{2 *}$

1. 安徽中医药大学药学院, 合肥 230012 ;

2. 中国中医科学院中药资源中心, 道地药材国家重点实验室培育基地, 北京 100700;

3. 江西省文物考古研究院, 南昌 330000 ;

4. 东华理工大学江西省质谱科学与仪器重点实验室, 南昌 330000;

5. 中国中医科学院中国医史文献研究所, 北京 100700;

6. 清华大学医学院医学系统生物学研究中心, 北京 100084

$\dagger$ 同等贡献

*联系人, E-mail: huangluqi01@126.com

2019-01-04 收稿, 2019-01-22 修回, 2019-01-23 接受, 2019-03-06 网络版发表

名贵中药资源可持续利用能力建设项目(2060302)和中央级公益性科研院所基本科研业务费(ZZ10-008)资助

摘要中药炮制技艺是国家级非物质文化遗产，体现了中医用药特点. 有关炮制药物的文字记载最早可追溯到 《黄帝内经》, 但是古代对炮制工艺的记载文字简短, 使复原传统技艺、实现“遵古炮制”存在一定困难. 因此古代 炮制药物的考古发现将为中药炮制的起源研究提供有力的实证. 西汉海昏侯墓园主墓(M1)中出土了由木质漆盒 盛装的样品，通过核磁及三维重建、显微分析，发现该样品是由外部辅料层和内部植物层构成. 结合显微特征、 质谱分析, 推测该样品中为玄参科地黄属Rehmannia植物的根, 且可能经过了热水等处理. 《神农本草经》记载地 黄具有“主折跌, 绝筋, 伤中. 逐血痹, 填骨髓, 长肌肉”等功效, 这与古代文史资料记载墓主生前患有严重的风湿病 相符. 样品的辅料层内含有淀粉粒与蔗糖, 这可能与炮制“矫味矫臭、利于服用”的作用有关. M1木质漆盒内遗存 样品是迄今报道的我国古代最早的中药辅料炮制品, 其发现和鉴定为深入了解我国古代药物炮制与应用历史奠定 了基础.

关键词 海昏侯墓园主墓, 中药炮制, 辅料, 蔗糖

中药必须经过炮制之后才能入药，是中医用药的 特点之一. 作为国家级非物质文化遗产之一，中药炮制 是指根据中医药理论，依据临床施药的需要和药物自 身性质, 选择适当的工艺, 将原生药材加工便于临床应 用的一项传统制药技术. 炮制, 古称“炮采”, “炮”和“采” 在中国古代都与烹任有关，可见古代中药炮制与烹制
食物密不可分 ${ }^{[1]}$.

有关炮制药物的文字记载最早可追溯到《黄帝内 经》 ${ }^{[2]}$. 《五十二病方》 ${ }^{[3]}$ 中也记载了应用辅料进行药 物炮制，包括酒渍、醋渍、药汁渍、酒煮、醋煮等方 法. 张仲景在《伤寒论》 ${ }^{[4]}$ 和《金豆要略》 ${ }^{[5]}$ 中所用方 剂中多数药物标注了需要炮制，说明汉代对药物炮制

引用格式: 彭华胜, 徐长青, 袁媛, 等. 最早的中药辅料炮制品: 西汉海昏侯墓出土的木质漆盒内样品鉴定与分析. 科学通报, 2019, 64: 935-947 Peng H S, Xu C Q, Yuan Y, et al. The earliest excipient products of Traditional Chinese Medicine: Identification and analysis of samples from wooden lacquer box unearthed from Haihunhou tomb in the Western Han Dynasty (in Chinese). Chin Sci Bull, 2019, 64: 935-947, doi: 10.1360/N972018-01176 
已非常重视. 但有关对古代炮制技术的记载, 文字过于 简略，使得复原传统技艺、实现“遵古炮制”存在一定 困难.

因此, 古代炮制药物的考古发现, 可为中药炮制的 起源研究提供有力的实证. 本文利用多种手段对江西 省南昌市新建区大塘坪乡观西村的海昏侯墓园主墓 (M1)中出土的木质漆盒内的样品进行分析, 认为其是 一种汉代中药辅料炮制品, 并对其原料和辅料进行鉴 定, 推测其炮制工艺, 为深人了解我国古代药物炮制与 应用历史提供依据.

\section{1 材料与方法}

\section{1 样品收集}

海昏侯墓 $\left(29^{\circ} 02^{\prime} 2.33^{\prime \prime} \mathrm{N}, 115^{\circ} 56^{\prime} 45.35^{\prime \prime} \mathrm{E}\right)$ 位于江西 省南昌市新建区大塘坪乡观西村. 2016年3月2日, 江西 省南昌市海昏侯墓墓主得到确认，是第一代海昏侯汉 废帝刘贺. 墓室被划分为车马库、娱乐用具库、武 库、钱库、粱库、乐器库、酒具库、欴具库等单元 (图1(a), (b)). 本文研究的样品遗存出土于M1楟室的娱 乐用具库, 与琴、棋等共处一室. 样品盛于精美的木质 漆盒, 呈多层叠加(图1(c) (e)).

\section{2 核磁及三维重建}

采用直径 $15 \mathrm{~mm}$ 的表面线圈射频谐振器, $7.0 \mathrm{~T}$ Bruker AVANCE微成像系统, 测定温度为常温. 将浸泡 在水中的样品装在 $1.5 \mathrm{~mL}$ EP管中, 置于样品槽, 使用 Flash模式收集样品图像信号. 图像像素 $256 \times 128 \times 128$. 成像时间为 $1 \mathrm{~s}$, 成像间隔 $6 \mathrm{~s}$. 图片亮度经对照(纯水) 校正.

\section{3 冰冻切片与显微观察}

横切面特征观察: 用锋利刀片切取长度为 $0.5 \mathrm{~cm}$ 的 样品, 置于冰冻切片机(Leica CM1850 UV, 德国)的托物 台上, 用冷冻包埋剂(SAKURA Tissue-Tek O.C.T. Compound 4583 , 美国)逐渐浸润后包埋, $-20^{\circ} \mathrm{C}$ 环境下冷凝 至包埋剂完全凝固, 切片厚度为 $20 \mu \mathrm{m}$, 用洁净载玻片 吸贴, 封片后置于苂光显微镜(Leica DM6000B, 德国) 下观察, LAS软件(Leica Application Suite V4.1)拍摄.

粉末特征观察: 用解剖针挑取少量样品于载玻片 上, 水装片和水合氯醛制片, 稀甘油封片. 观察方法 同上.

\section{4 出土植物样品的ESI-MS分析}

(i) 仪器与材料. 线性离子阱静电场轨道阱质谱 仪, 配有Xcalibur数据处理系统(LTQ Orbitrap XL, Thermo Fisher Scientific, 美国); ESI离子源(江西省质谱科学 与仪器重点实验室自制, 中国); 超纯水处理系统(Thermo Fisher Scientific, 美国). 对照样品: 天目地黄(采于安 徽黄山, 由安徽中医药大学彭华胜教授鉴定为玄参科 植物天目地黄Rehmannia chingii H. L. Li 的块根); 甲 醇(色谱纯, Tedia, 美国).

(ii) 样品处理. 将出土样品和天目地黄块根粉碎 成较小的不规则颗粒, 分别取适量置于 $0.22 \mu \mathrm{m}$ 的微孔 滤头中备用.

(iii) 质谱条件. ESI-MS设置为负离子检测模式, 质谱扫描范围 $m / z$ : 50 1000; 喷雾电压为 $-3.5 \mathrm{kV}$; 离子 传输管温度为 $200^{\circ} \mathrm{C}$; 毛细管电压为 $-40 \mathrm{~V}$; 透镜电压为 $-100 \mathrm{~V}$; 萃取剂甲醇-水混合溶液(体积比 $1: 1$ )通过注射 泵进样, 流速 $4.0 \mu \mathrm{L} / \mathrm{min}$. 喷雾气 $\left(\mathrm{N}_{2}\right)$ 压力为 $0.8 \mathrm{MPa}$ (氮 气钢瓶表头压力). 在进行串联质谱分析时, 母离子的选 择窗口为 $1.0 \mathrm{Da}$, 碰撞时间为 $30 \sim 50 \mathrm{~ms}$, 碰撞能量为 $10 \% \sim 30 \%$, Act. $\mathrm{Q}$ 为 0.25 . 其他参数由LTQ-Orbitrap-MS 系统自动优化产生.

\section{5 扫描电子显微镜(SEM)能谱分析}

采集样品外围辅料层中的晶体进行扫描电子显微 镜能谱分析, 使用仪器为FEI Sirion200场发射扫描电子 显微镜(FEI, 美国)观察晶体形貌, 用X射线能谱仪 (INCA, Oxford, 英国)对样品进行微区元素分析. 检测 器为 $\mathrm{Si}(\mathrm{Li})$ 探测器. 实验条件为: SEM加速电压为 $20 \mathrm{kV}$, 工作距离是 $15 \mathrm{~mm}$. 样品的测试在中国科学技术大学理 化实验中心完成.

\section{6 辅料层中糖类成分的UPLC-Q-TOF-MS鉴定}

(i) 仪器与材料. Acquity UPLC-I-Class串联XevoG2-S Q-TOF质谱联用仪, 配有Masslynx 4.1质谱工作站 (Waters, 美国), UNIFY1.7数据库(Waters, 美国), 离心机 (Eppendorf, 德国), KQ-100DE超声清洗器(昆山市超声 仪器有限公司), $0.2 \mu \mathrm{m}$ 注射器式滤器(Pall, 美国).

试剂: 乙腈, 甲醇, 氨水(色谱纯, Merck, 德国); 超纯 水由Milli-Q纯水制备系统(电阻 $\geqslant 18.2 \mathrm{M} \Omega \mathrm{cm}$, Millipore, 美国). 对照品：无水葡萄糖(批号：110833201707), D-果糖(批号：111504-201703), 蔗糖(批号: 

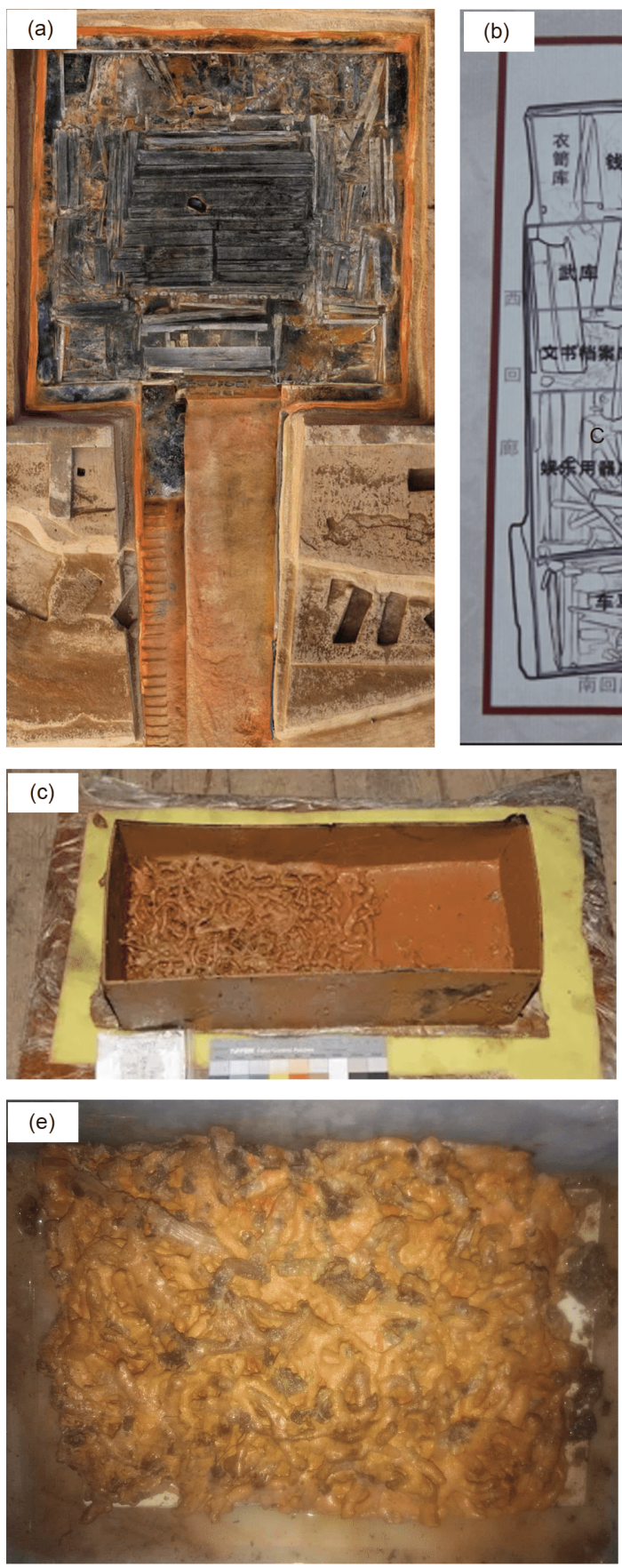

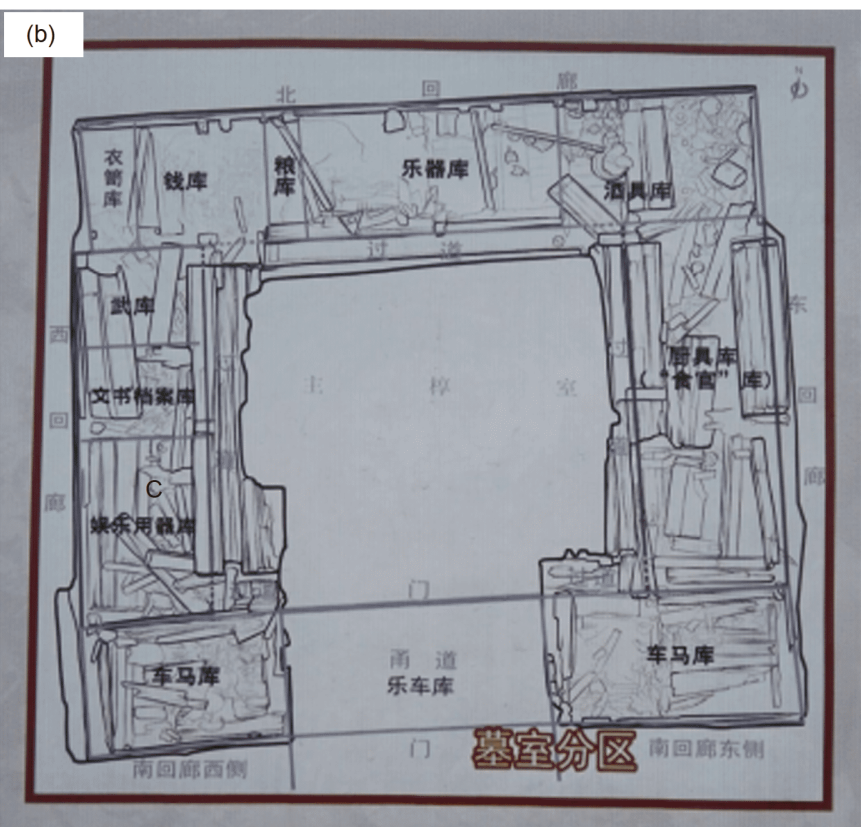

(d)
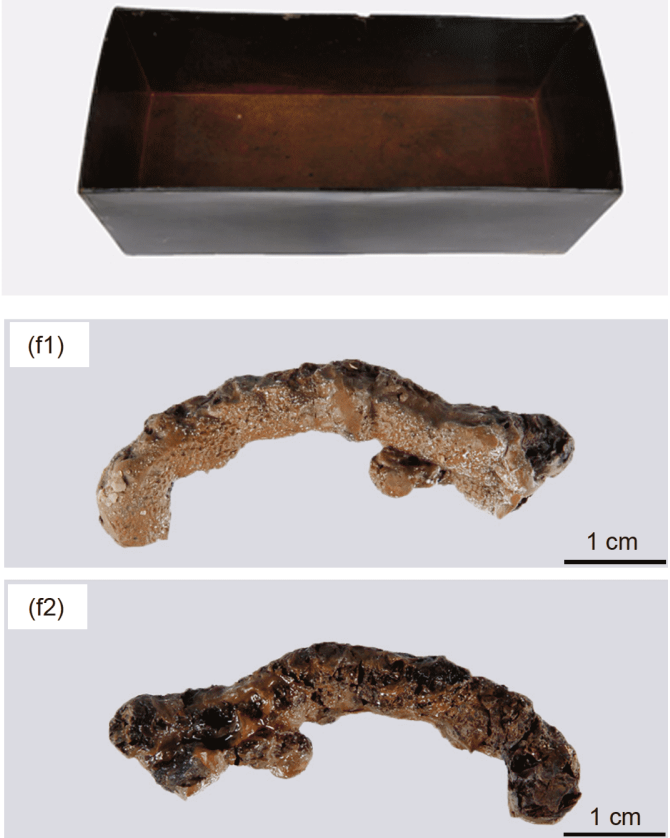

图 1 海昏侯墓园主墓(M1)以及本文研究样品. (a) M1的正射影像图; (b) 海昏侯墓室分区; (c) 出土样品及其漆盒; (d) 盛样品的漆盒; (e) 样品呈 多层叠加; (f1), (f2) 单个样品的正面观与反面观

Figure 1 The Haihunhou tomb (M1) and the unearthed samples studied in this study. (a) The orthophoto map of M1; (b) the partitions of Haihunhou tomb; (c) the unearthed samples and lacquer box; (d) lacquer box for samples; (e) the samples were stacked on top of each other; (f1), (f2) characteristics of the front and the back of sample

111507-201704), 麦芽糖(批号: 100287-201604), 均购自 中国食品药品检定研究院, 含量 $99.9 \%$ 以上.

（ii）供试品及对照品溶液制备. 刮取样品临时制 片的外侧辅料层作为供试品. 用灭菌枪头挑取小块供
试品置于 $2.0 \mathrm{~mL}$ 无菌EP管中, 加人 $200 \mu \mathrm{L}$ 超纯水, 室温 超声提取 $40 \mathrm{~min}, 12000 \times g$ 离心 $10 \mathrm{~min}$, 取上清液经 $0.22 \mu \mathrm{m}$ 微孔滤膜过滤, 即得供试品溶液, 备用. 另取 $2.0 \mathrm{~mL}$ 无菌 $\mathrm{EP}$ 管，加人 $200 \mu \mathrm{L}$ 超纯水，同等条件处理， 
即得空白对照溶液. 分别取无水葡萄糖、 $D$-果糖、蔗 糖和麦芽糖对照品适量, 精密称定, 置 $5 \mathrm{~mL}$ 容量瓶中, 加超纯水溶解, 并稀释到刻度, 分别制得浓度为 0.98 , $0.54,0.78,0.54 \mathrm{mg} / \mathrm{mL}$ 单一对照品储备液, 混合对照品 储备液由各对照品储备液混合并稀释得到, 均置于 $4^{\circ} \mathrm{C}$ 保存.

(iii) 色谱条件. 色谱柱为Acquity UPLC BEH Amide C18 (2. $1 \mathrm{~mm} \times 100 \mathrm{~mm}, 1.7 \mu \mathrm{m})$; 流动相A: 0.1\% 氨水-乙腈溶液, 流动相B: $0.1 \%$ 氨水-水溶液; 梯度洗脱 (0 0.5 min, 98\% A; $0.5 \sim 2.0 \mathrm{~min}, 98 \% \sim 90 \% \quad \mathrm{~A}$; 2.0 5.5 min, 70\% 64.1\% A; 5.5 7.0 $\min 64.1 \% \sim 62.5 \%$ A; 7.0 7.2 $\min 62.5 \% \sim 98 \% \mathrm{~A} ; 7.2 \sim 10.0 \min 98 \% \mathrm{~A}$ ); 柱 温 $40^{\circ} \mathrm{C}$; 流速 $0.2 \mathrm{~mL} / \mathrm{min}$, 进样量 $2 \mu \mathrm{L}$.

(iv) 质谱条件. 数据采集模式: 负离子(ESI)条件 下采用continuum模式, 用碘化钠校正液校正质量范围 $m / z 50 \sim 2500$; 毛细管电压 $-2.5 \mathrm{kV}$, 雉孔电压 $-50 \mathrm{~V}$, 电 离源温度 $100^{\circ} \mathrm{C}$, 脱溶剂温度 $450^{\circ} \mathrm{C}$; 脱溶剂气流速 $900 \mathrm{~L} / \mathrm{h}$, 低能量通道碰撞能量为 $10 \mathrm{eV}$, 高能量扫描碰 撞能量为 $50 \sim 80 \mathrm{eV}$.

\section{2 结果}

\section{1 出土样品的结构特征}

单根样品长 5 7 cm, 直径约 $1 \mathrm{~cm}$, 多弯曲, 有的具 短小分支(图1(f1), (f2)). 由核磁拍摄的三维图像可见, 出土的样品为中空不规则棒状结构, 外层是信号强度 较弱的物质, 且未见细胞结构; 内层具类似植物的纤维 结构, 含水量高, 信号强 (图2).

对样品进行冰冻切片, 并观察横切面特征, 发现该 样品中部具周皮、细胞、导管等植物组织结构; 外围 为辅料层, 约有 2 3层状结构(图3(a), (b)). 辅料层呈不 均匀分布, 即具上方厚、下方薄特征 (图3(a), (b)).

\section{2 植物遗存基原推测}

\subsection{1 植物遗存的显微特征}

植物遗存的横切面显微观察可见在外方具有周皮 (图3(d1)), 且导管呈纵向排列(图3(d2)), 具次生木质部 及宽广的木射线(图3(d2), (d3)). 可推断其来自于双子 叶草本植物的根、根状茎或茎. 另外, 在植物遗存的横 切面和粉末中均可见导管, 导管类型多为梯纹和网纹 (图3(d6)), 红棕色细胞单个或2 3个呈团, 未观察到淀 粉粒、草酸钙晶体与石细胞等.

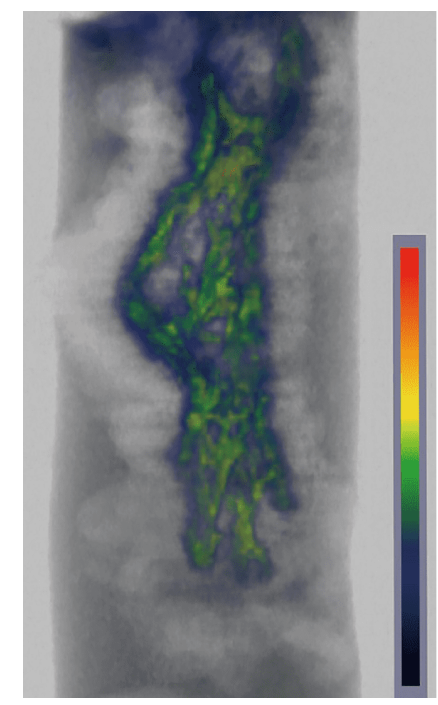

图 2 西汉海昏侯墓墓园主墓出土的木质漆盒内样品的micro-CT图 Figure 2 Micro-CT image of sample in wooden lacquer box unearthed from Haihunhou Han tomb

在中国中医科学院中药资源中心建立的药材显微 数据库中提取双子叶草本植物的根、根状茎、茎或全 草等显微数据, 再根据具有红棕色细胞或红棕色细胞 团这一特征, 对显微数据进行第 2 次筛选; 根据出土样 品中植物层的直径与长度, 排除数据库中粗大的块 根、短小的块根或块茎等植物种类; 根据出土样品具 有次生结构特征, 排除具有初生构造的植物种类. 再结 合全国第4次中药资源普查所收集的样品 ${ }^{[6]}$ 开展显微比 较研究, 根据出土样品中植物具有宽广的木射线这一 典型特征, 推测出土样品来源于玄参科地黄属Rehman$n i a$ 植物的根.

由于地黄属植物的栽培始见于南北朝时期《齐民 要术》 ${ }^{[7]}$, 因此推测西汉时期使用的地黄属植物可能取 自野生资源. 根据《中国植物志》 ${ }^{[8]}$ 记载, 中国有 6 种地 黄属植物, 其中在江西及其周边省份分布的有地黄 $R e-$ hmannia glutinosa (Gaertner) Liboschitz ex Fischer \& C. A. Meyer, 天目地黄Rehmannia chingii H. L. Li, 湖北 地黄Rehmannia henryi N. E. Brown, 裂叶地黄Rehmannia piasezkii Maximowicz, 高地黄Rehmannia elata N. E. Brown ex Prain等.

为进一步确认地黄属Rehmannia植物的显微特征 与出土样品是否一致, 本文收集了天目地黄Rehmannia chingii H. L. Li 的根作比较研究. 天目地黄的根系由数 条根组成, 外表黄红色、肉质 (图4(a)), 其特征与宋代 《本草图经》 ${ }^{[9]}$ 记载地黄“根如手指, 通黄色, 粗细长短 

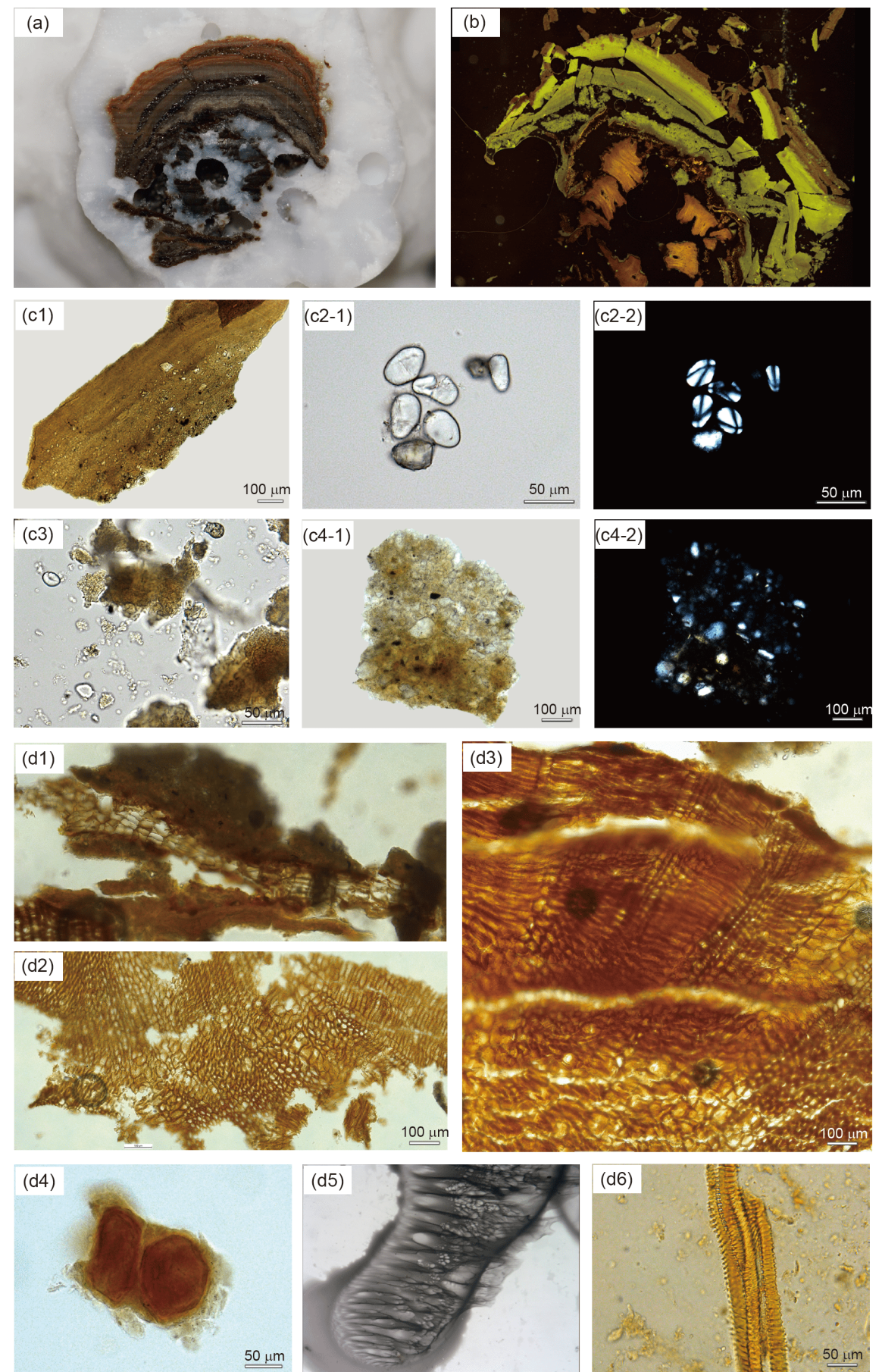

图 3 海昏侯墓园主墓出土的木质漆盒内样品的显微结构. (a) 冰冻切片机下的样品断面, 显示辅料层和植物两部分, 白色为冰冻状态下的胶水; (b) 显微镜下的样品断面, 显示辅料层和植物两部分; (c1) 辅料层的碎片; (c2-1) 辅料层中淀粉粒(明场); (c2-2) 辅料层中淀粉粒(偏光); (c3) 辅料 层的碎片; (c4-1) 辅料层中含晶体的团块物(明场); (c4-2) 辅料层中含晶体的团块物(偏光); (d1) 植物的周皮; (d2) 次生木质部, 含有导管和薄壁 组织; (d3) 次生木质部, 含有导管和宽广的木射线; (d4) 红棕色细胞; (d5) 植物组织与磾-碘化钾试液显特异蓝色; (d6) 植物的导管

Figure 3 The microstructure of sample in wooden lacquer box unearthed from Haihunhou Han tomb. (a) The sample cross section in freezing microtome, showing the excipients and plants, with white frozen glue; (b) the sample section under microscope, showing excipient layers and plants; (c1) fragments of excipient layers; (c2-1) starch granules in excipient layers (bright-field); (c2-2) starch granules in excipient layers (polarized-light); (c3) fragments of excipient layers; (c4-1) one of the masses containing crystals in the excipient layers (bright-field); (c4-2) one of the masses containing crystals in the excipient layers (polarized-light); (d1) periderm; (d2) secondary xylem containing vessels and parenchyma cells; (d3) secondary xylem containing vessels and rays; (d4) reddish brown cells; (d5) the reaction between plant tissues and iodine-potassium iodide test solution showing characteristic blue; (d6) vessels 

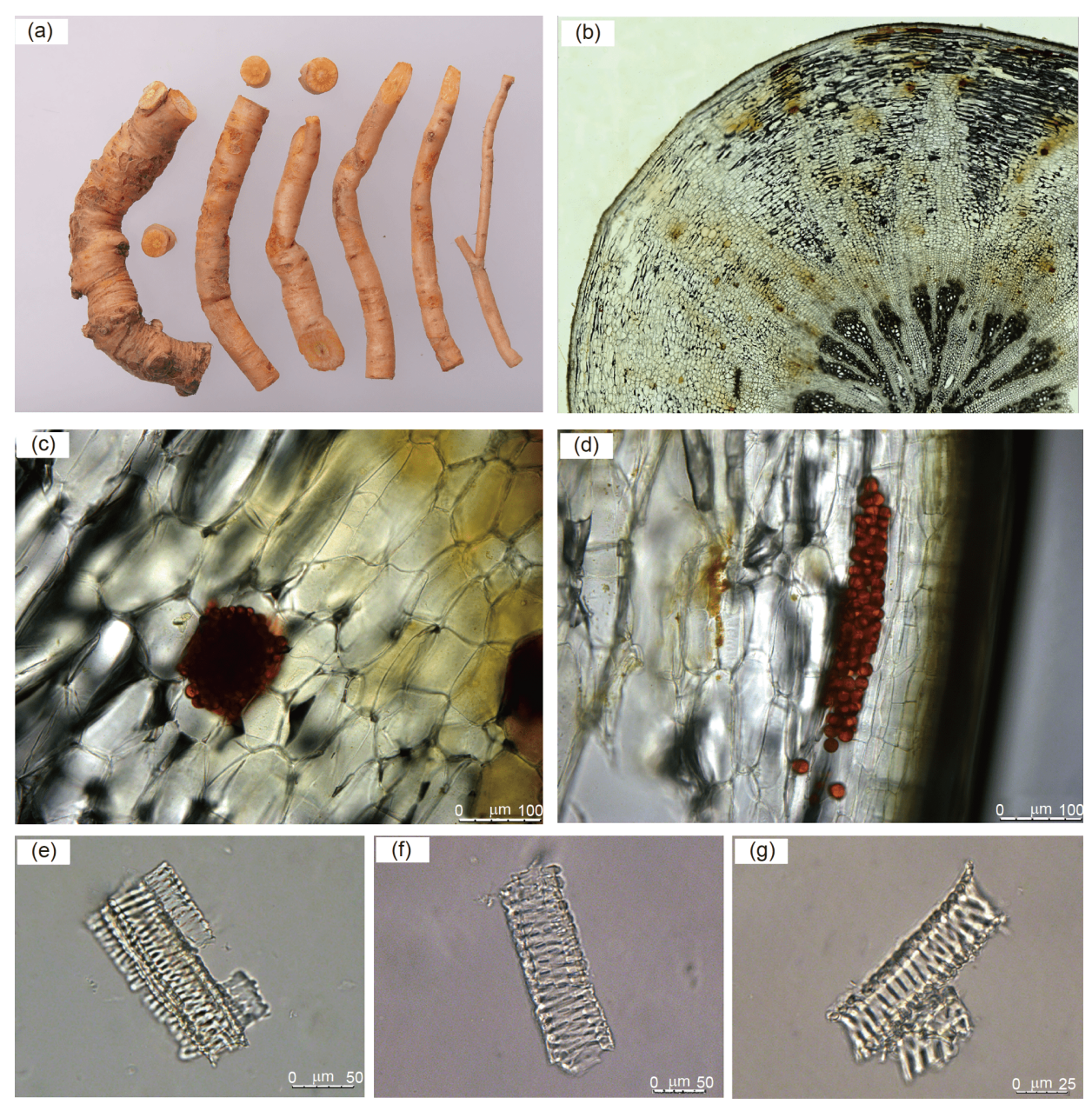

图 4 天目地黄的根及其显微结构. (a) 根外观形状; (b) 根的横切面; (c), (d) 分泌细胞; (e), (f), (g) 导管

Figure 4 The roots and its microstructure of Rehmannia chingii. (a) Appearance characteristics; (b) transverse section; (c), (d) secretory cells; (e), (f), (g) vessels

不常”一致. 显微特征比较结果表明，天目地黄与出土 样品均具有周皮、宽广的次生韧皮部和木射线(图3 (d3), 4(b)), 导管形态也基本一致 (图3(d6), 4(e) (g)), 且 均有红棕色细胞 (图3(d4), 4(c), (d)). 但天目地黄根中红 棕色细胞内散有红色颗粒状物质 (图4(c), (d)), 出土样 品中的红棕色细胞未见红色颗粒状物质(图3(d4)). 这可 能与地黄块根的红棕色细胞中存在橘黄色油滴所含有 的地黄黄素B, D等物质在空气中易褪色有关 ${ }^{[10,11]}$.

\subsection{2 植物遗存的化学特征}

对出土样品及天目地黄进行ESI-MS分析, 得到化 学指纹图谱(图5(a), (c)). 出土样品和天目地黄均具有 丰富的质谱信息, 且存在明显差异. 为验证出土样品是 否为天目地黄, 以天目地黄为对照, 收集了其特征化合
物 $^{[12 ~ 14]}$ 在高分辨负离子模式下的质谱数据, 并与出土 样品进行比对. 分别选择了 $[\mathrm{M}-\mathrm{H}]^{-} \mathrm{m} / \mathrm{z} 361, \mathrm{~m} / \mathrm{z} 363$, $\mathrm{m} / \mathrm{z} 523, \mathrm{~m} / \mathrm{z}$ 685, $\mathrm{m} / \mathrm{z} 509, \mathrm{~m} / \mathrm{z} 347, \mathrm{~m} / \mathrm{z}$ 785, $\mathrm{m} / \mathrm{z} 345, \mathrm{~m} / \mathrm{z}$ $623, m / z$ 651进行高分辨质谱分析, 发现出土样品的高 分辨质谱信息与天目地黄的高分辨质谱信息存在一定 的差异. 其中, 两者 $m / z 623$ 的高分辨质谱信息吻合, 但 出土样品中 $m / z$ 623的离子信号强度较低(图5(b1), (d1)). 在二级质谱中, 两者质谱图相似(图5(b2), (d2)), 相对丰 度为 $100 \%$ 的二级质谱碎片离子 $\mathrm{m} / \mathrm{z} \quad 461$ 为母离子 $\mathrm{m} / \mathrm{z}$ 623 丢失咖啡酰基后形成，推测可能为毛莣花糖苷或连 趐酯苷. 两者均为天目地黄的特征性成分 ${ }^{[12]}$.

由于出土样品经历了长时间的地下保存, 推测其 特征成分可能发生降解, 样品中可能会出现毛芯花糖 苷或连翅酯苷的水解产物. 由于毛芯花糖苷或连翅酯 


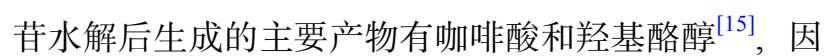
此选择 $[\mathrm{M}-\mathrm{H}]^{-} m / z \quad 179$ 和 $m / z \quad 153$ 进行高分辨分析, 其 中 $m / z$ 179在高分辨质谱中检测的质荷比为 179.0349 (图 5(f1)), 推测其分子式为 $\mathrm{C}_{9} \mathrm{H}_{7} \mathrm{O}_{4}$, 与理论值偏差为 $5.7 \mathrm{ppm}$. 二级质谱中，相对丰度为 $100 \%$ 的二级质谱碎 片离子 $m / z \quad 135$ 为母离子 $m / z \quad 179$ 丢失 $\mathrm{CO}_{2}$ 后形成(图 5 (f2)), 与文献记载咖啡酸的裂解方式一致 ${ }^{[16,17]}$, 故推测 该化合物为咖啡酸.

\section{3 植物遗存炮制技艺的推测}

\subsection{1 热水处理后加辅料层}

出土样品由内部的植物层及其外围的辅料层构成. 分别对植物层、辅料层进行水装片观察，在辅料层横 切面和粉末制片中均发现存在淀粉粒(图3(c2-1), (c22)), 表明出土样品中的淀粉粒没有因为长期埋藏在地 下而遭受破坏。

出土样品植物层的横切面制片与粉末制片中均未 发现淀粉粒(图3(d1) (d3)). 但对植物横切面或粉末滴 加碘-碘化钾试液, 则呈特殊的蓝色(图3(d5)). 对天目 地黄Rehmannia chingii H. L. Li 的根进行新鲜切片, 未 见淀粉粒. 同属植物地黄Rehmannia glutinosa (Gaertner) Liboschitz ex Fischer \& C. A. Meyer的根中没有淀
粉粒 ${ }^{[18,19]}$, 地黄块根的不同发育阶段也未见有淀粉粒 报道 ${ }^{[20]}$. 出土样品的植物外面裹有厚厚的辅料层, 辅料 层横切面和粉末的水装片可以观察到清晰的淀粉粒, 据此推测出土样品辅料层中的淀粉粒来源于外源添加 物, 不是植物材料自身的淀粉粒.

尽管出土样品的植物层未发现淀粉粒, 但是对其 横切面或粉末水装片中滴加硒-碘化钾试液, 则呈特殊 的蓝色(图3(d5)). 由此可以推断出土样品中的植物层 中有糊化的淀粉粒，使其与碘-碘化钾试液反应呈现特 殊蓝色. 淀粉粒糊化是指当淀粉分散到水中并加热到 一定温度后，淀粉粒原具有的半结晶结构中的有序分 子变为无序状态 ${ }^{[21]}$. 推测原植物材料或与部分含淀粉 类辅料经过了水及加热等加工过程，从而使淀粉粒发 生糊化现象. 出土样品的辅料层中可观察到大量清晰 的淀粉粒，说明植物材料有可能在经过水及加热后再 裹上淀粉类辅料层进行使用或贮存.

\subsection{2 辅料层含有蔗糖}

出土样品辅料层中散有大量的晶体, 在偏光显微 镜下可显示偏光特性(图3(c4-1), (c4-2)). 将少许辅料层 放置盐酸或 $\mathrm{NaOH}$ 试液中, 发现该晶体不溶于盐酸或 $\mathrm{NaOH}$ 试液. 应用扫描电子显微镜-能谱分析, 发现该晶
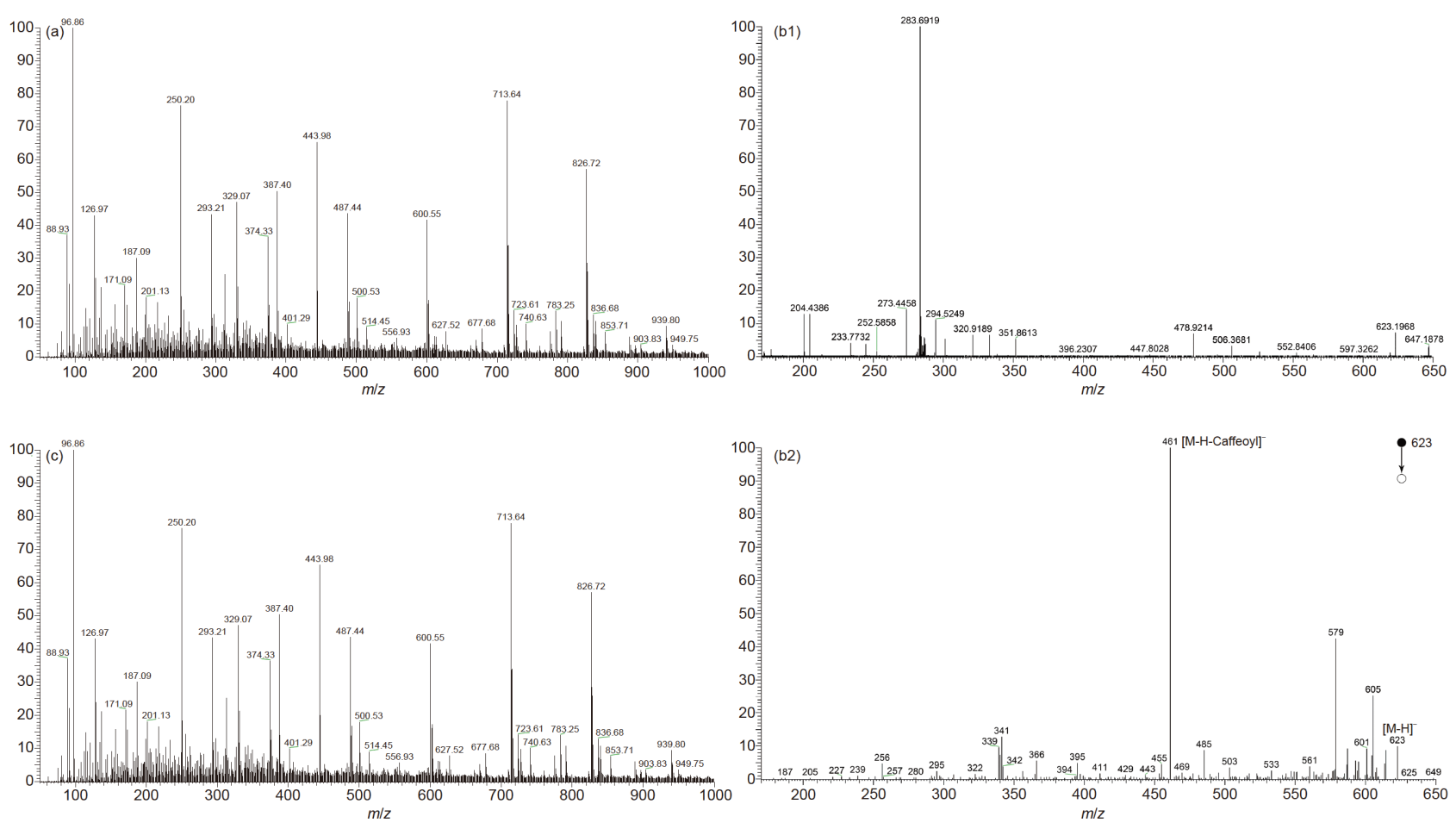

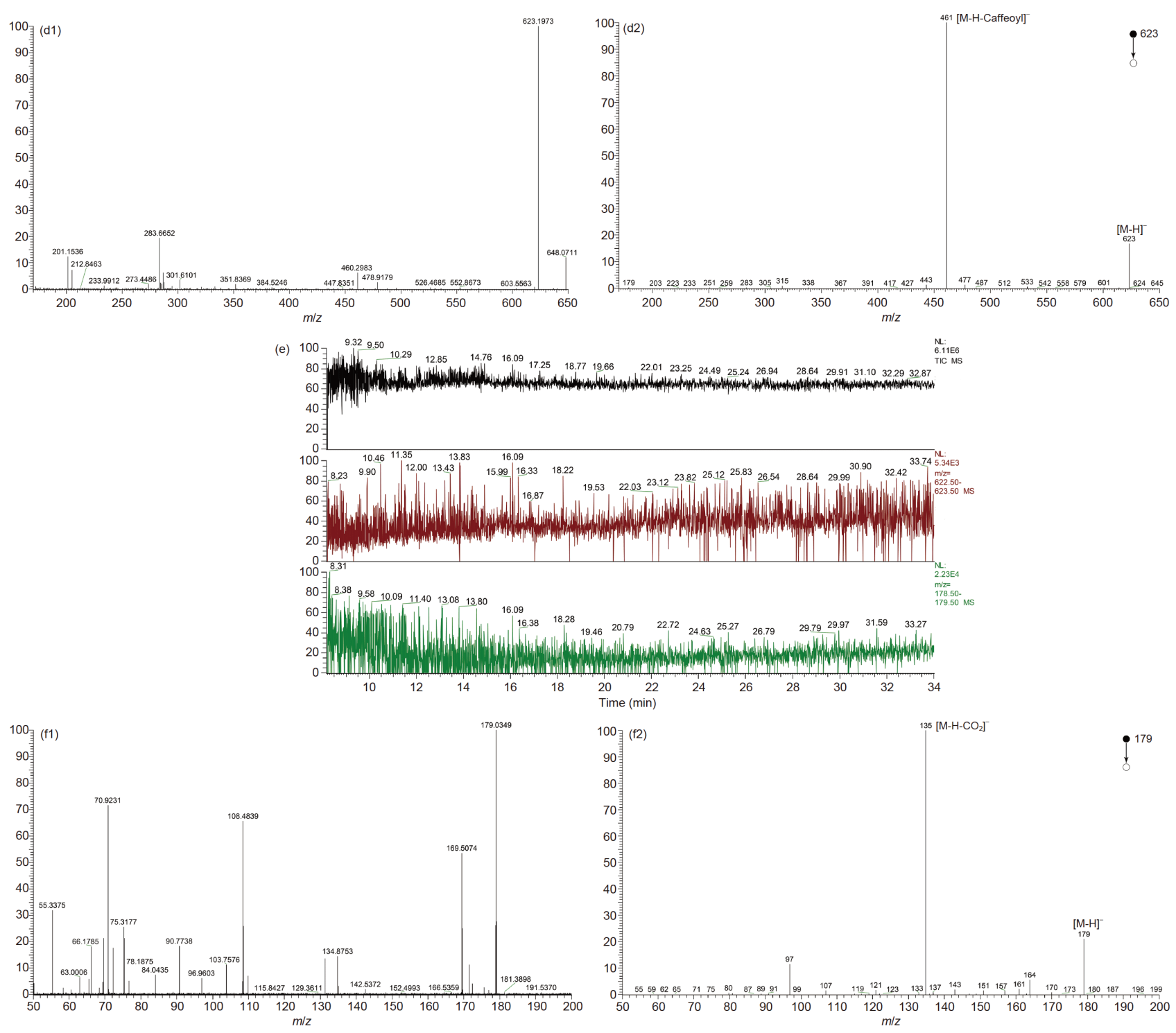

图 5 出土样品和天目地黄的ESI-MS化学指纹谱图. (a) 出土样品一级质谱图; (b1) 出土样品 $m / z$ 623一级质谱图; (b2) 出土样品 $m / z$ 623 MS/MS 图; (c) 天目地黄一级质谱图; (d1) 天目地黄 $\mathrm{m} / \mathrm{z}$ 623一级质谱图; (d2) 天目地黄 $\mathrm{m} / \mathrm{z} 623 \mathrm{MS} / \mathrm{MS}$ 图; (e) 出土样品中的总离子图和选择离子图 $(\mathrm{m} / \mathrm{z}$ 623 和 $m / z$ 179); (f1) 出土样品 $m / z$ 179一级质谱图; (f2) 出土样品 $m / z 179 \mathrm{MS} / \mathrm{MS}$ 图

Figure 5 ESI-MS spectra of unearthed sample and Rehmannia chingii. (a) MS spectrum of unearthed sample; (b1) MS spectrum of $m / z 623$ in unearthed sample; (b2) MS/MS spectrum of $m / z 623$ in unearthed sample; (c) MS spectrum of $R$. chingii; (d1) MS spectrum of $m / z 623$ in $R$. chingii; (d2) MS/MS spectrum of $\mathrm{m} / \mathrm{z} 623$ in $R$. chingii; (e) TIC and SIM spectra $(\mathrm{m} / \mathrm{z} 623$ and $\mathrm{m} / \mathrm{z}$ 179) of unearthed sample; (f1) MS spectrum of $m / z 179$ in unearthed sample; (f2) MS/MS spectrum of $m / z 179$ in unearthed sample

体主要由 $\mathrm{C}$ 和 $\mathrm{O}$ 元素组成.

对样品辅料层的水提物进行UPLC-Q-TOF-MS分

析, 检测到 $m / z$ 341.11的特征离子碎片峰(图6(a)); 将离 子流图中 $m / z \quad 341.11$ 的碎片离子峰分别与葡萄糖、蔗 糖、果糖、麦芽糖4种糖对照品进行比较, 发现其与蔗 糖的保留时间一致，且质谱图与蔗糖对照品质谱图基 本一致(图6(a) (d)). 对辅料层水提物进行梯度进样, 结
果表明 $m / z \quad 341.11$ 碎片离子峰的峰面积与浓度成正比, 从而推测外侧辅料层中含有蔗糖.

同时对出土样品的植物层进行剥离，并对其水提 物进行UPLC-Q-TOF-MS分析，发现 $m / z$ 341.11碎片离 子峰的峰面积很小，表明植物中蔗糖含量明显低于辅 料层. 推测辅料层中的蔗糖为外源性添加物, 而非植物 内源性蔗糖. 

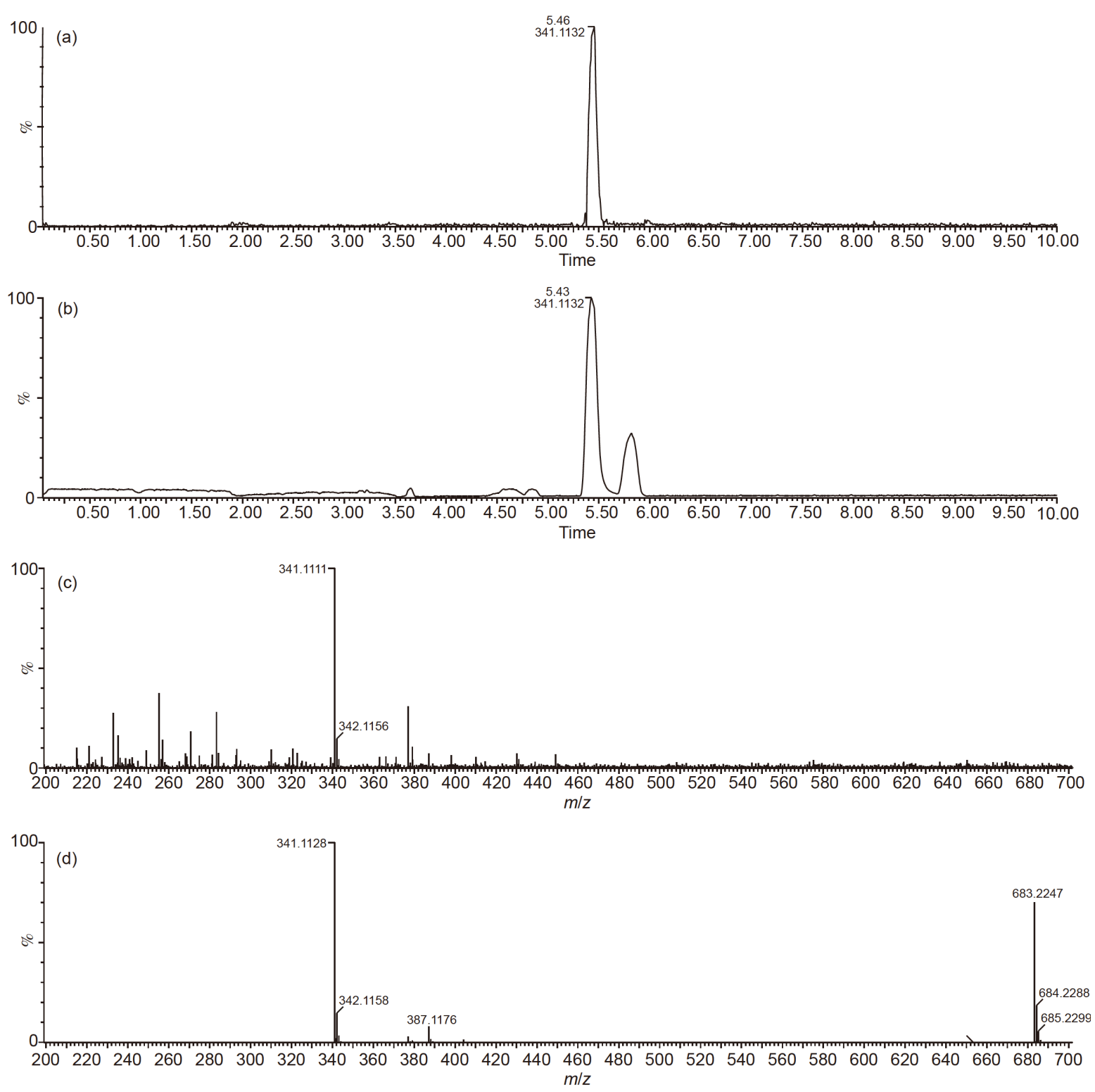

图 6 UPLC-Q-TOF-MS提取离子流色谱图及其质谱图. (a) 样品辅料层水提物提取离子流色谱图; (b) 4种糖对照品总离子流色谱图; (c) 样品辅 料层水提物中 $m / z$ 341.11峰的质谱图; (d) 4种糖对照品中蔗糖的质谱图

Figure 6 UPLC-Q-TOF-MS total ion chromatograms and mass spectrograms. (a) The ion chromatograms of excipient layers aqueous extract; (b) the total ion chromatograms of glucose, sucrose, fructose, maltose; (c) mass spectrogram of $m / z 341.11$ peak in aqueous extract of excipient layers; (d) mass spectrogram of sucrose

\section{3 讨论}

\section{1 遗存样品的作用推测}

海昏侯墓墓主的身份得到确认，是第一代海昏侯 汉废帝刘贺. 刘贺是西汉第9位皇帝, 在位27天, 是西汉 历史上在位时间最短的皇帝. 刘贺被废黜后, 汉宣帝即 位. 《汉书·武五子传》 ${ }^{[22]}$ 记载昌邑所在地的山阳太守 张敞地节四年(公元前66年)曾亲自人刘贺居处查看, 并
向宣帝报告了刘贺的身体状况：“故王年二十六七，为 人青黑色，小目，鼻末锐卑，少须眉，身体长大，疾瘘， 步行不便. 衣短衣大绔…篧笔持牍趋谒…察故王衣服 言语跪起, 清狂不惠.” “瘘”, 《说文解字》 ${ }^{[23]}$ 解释为: “痺疾”. 《汉书·艺文志》 ${ }^{[22]}$ 著录有《五藏六府痺十二 病方》30卷，颜师古注曰: “痺，风湿之病.”《素问·痹 论》 ${ }^{[24]}$ : “风寒湿三气杂至，合而为痹也.”据此，古代 中医认为, “痹”症多由风寒湿引发. 海昏侯墓的主楟室 
西堂、东寝的棺楟旁边各发现了一张床榻, 均有 $2 \mathrm{~m}$ 多 长. 不论是堂还是寝, 汉墓基本上都是按照逝者生前生 活、工作等习惯设置, 即“视死如视生”. 按照礼制, 堂 是海昏侯接待宾客和办公的地方, 应放置坐榻而不是 床榻. 由此可以推断墓主海昏侯生前在接待宾客或办 公时需要床榻. 这与张敞描述刘贺曾患有比较重的风 湿病、行动不便相吻合.

《神农本草经》 ${ }^{[25]}$ 收录干地黄, 列为上品: “味甘, 寒. 主折跌, 绝筋, 伤中. 逐血痹, 填骨髓, 长肌肉. 作汤 除寒热积聚, 除痹. 生者尤良. 久服轻身不老”. 地黄“主 折跌, 绝筋, 伤中. 逐血痹, 填骨髓, 长肌肉”, 与墓主刘 贺“疾瘘, 步行不便”等病证相对应. 《神农本草经》收 载365味药中, 记载“生者尤良”仅地黄一味药. “生者”, 与干地黄相对而言, 指未经干燥的地黄, 即新鲜的地 黄根.

南北朝时期《雷公炮多论》 ${ }^{[26]}$ 详细记载了地黄的 炮制方法: “采生地黄去白皮, 瓷锅上柳木甑蒸之, 推令 气歇, 拌酒再蒸, 又令出干. 勿令犯铜铁器, 令人肾消并 白髭发, 男损荣, 女损卫也.”该炮制方法提及了用蒸、 拌酒再蒸等水火共制的炮制方法, 与出土样品中植物 经过了水、加热等加工方法相一致. 另外, 海昏侯墓中 出土了大量金器、青铜器、铁器、玉器等. 其中青铜 器3000余件(套), 包括蒸馏器、蒸煮器、鼎等, 金器 478 件, 约 $115 \mathrm{~kg}^{[27]}$. 但是本文所研究的M1中出土样品 盛于漆木盒, 而不是盛于金属器血, 可能与《雷公炮采 论》记载地黄“昒令犯铜铁器”有关.

\section{2 样品辅料中蔗糖的来源推断}

分别利用显微和UPLC-Q-TOF-MS对出土样品的 辅料层与植物层进行分析, 发现其含有淀粉和蔗糖, 均 被推测属于外源添加物.

我国学者季羡林先生著《蔗糖史》 ${ }^{[28]}$, 该书对我 国乃至世界蔗糖的发现、加工与交流等作了系统论述. 我国先秦古籍中有“飴”, 汉代有“餳”、“餹”等字, 据季 羡林研究应为糯米或小麦、大麦制成的甜品. 糯米或 小麦、大麦制成的糖制品以含麦芽糖为主要成分. 天 然的蜂蜜含有丰富的糖类，约占总成分的 $70 \% \sim 80 \%$, 但以果糖、葡萄糖等单糖为主要成分, 约占总成分的 $65 \%$ 以上, 其次才是双糖. M1中出土的木质漆盒内样 品辅料层含有的蔗糖为双糖, 因此可以排除来自天然 蜂蜜、糯米或麦类制成的糖制品.

据季羡林先生《蔗糖史》, 中国蔗糖的制造始于
三国魏晋南北朝到唐代之间的某一个时代 ${ }^{[28]}$, 海昏侯 刘贺生活的时代可能还没有蔗糖的制造. 又据《蔗糖 史》 ${ }^{28]}$ 研究: 先秦至六朝的典籍中已经记载甘蔗, 当时 甘蔗尚属名贵, 还没有走人寻常百姓家; 甘蔗产地基本 都在南方, 如吴、蜀、江南等地; 甘蔗的用法包括生 吃、饮蔗浆. 刘贺居住地为江西省南昌市, 为汉代甘蔗 产区范围, 虽然甘蔗没有走人寻常百姓家, 但对于身为 海昏侯的刘贺而言应不足为奇. 因此, 推测出土样品辅 料层中的蔗糖可能来自甘蔗.

\section{3 中药炮制中辅料制法的起源可能与矫味矫臭、 利于服用有关}

中药炮制技艺是中医用药的特点之一, 富有中医 药文化特色. 中药炮制最早的记载是“咀”. 《说文解 字》 ${ }^{[23]}$ 作“哺咀”, 本义为咀嚼、嚼碎, 后来引申为捣 碎、切细、修药诸义. 目前出土的西汉经方文献中, 多 已用其引申义, 作为对药物粗加工的一道工序. 《五十 二病方》 ${ }^{[29]}$ 有3处出现“咀”.

炮制，古代又称为“炮采”. “炮”和“多”在中国古代 均与烹饪有关. 随着食物烹饪和药物加工经验的积累, 中药炮制从简单的挑选、剥离、清洗、切削演变到 炒、蒸、煮、煅、发酵等复杂方法, 初步形成了火 制、水制、水火共制等炮制方法; 另一方面, 随着酒、 蜂蜜、醋、盐等在食物、药物中的应用, 炮制中产生 了辅料制法 ${ }^{[1]}$. 辅料的使用是古代药物炮制发展的重 要阶段, 《伤寒杂病论》 ${ }^{[30]}$ 中已记载少数药物用辅料 进行炮制, 如大黄酒洗、猪肤加白粉白蜜謷至有香 气等.

地黄属Rehmannia植物的根, 味甜带苦, 未见生食 记载. 宋代罗愿《尔雅翼》 ${ }^{[7]}$ 记载: “芐者, 今之地黄. 古 以为菜, 铏美用之. ”由此可以看出, 食用新鲜地黄需要 进行适当的加工炮制. 通过对出土样品进行分析, 推断 其植物的根可能经过热水处理后, 外裹上一层含有蔗 糖的辅料，这与当前炮制具有“矫味矫臭、利于服用” 的作用一致.

\section{4 最早中药炮制品的工艺复原}

木质漆盒内样品由植物根与其外的辅料层组成, 是迄今发现最早的中药炮制品. 依据上述分析结果, 可 推测其炮制加工工艺, 即取地黄属Rehmannia植物的根 或与其他淀粉类辅料进行蒸或煮制, 再裹以甘蔗汁和 淀粉类等辅料. 
明朱权在《㺟仙神隐书》 ${ }^{[31]}$ 中记载了地黄粥: “大 能利血生精. 地黄切二合, 与米同人罐中煮之, 候熟, 以 酥二合, 蜜一合，同炒香人内，再煮熟食”. 朱权为明太 祖第十七子, 封地也在南昌, 说明在南昌有将地黄与米
共煮后再与酥、蜜共制的炮制历史. 出土样品与《睢 仙神隐书》中地黄粥在功效和工艺方面可谓异曲同工. 复原最早的中药炮制品加工工艺，将为了解中药炮制 技艺的起源奠定基础.

\section{参考文献}

1 Yang M, Zhang D K, Zhong L Y, et al. Study on culture and philosophy of processing of traditional Chinese medicines (in Chinese). China J Chin Mater Med, 2013, 38: 2223-2226 [杨明, 张定堮, 钟凌云, 等. 对传统中药炮制文化与哲学的思考. 中国中药杂志, 2013, 38: 2223-2226]

2 Li W. Huangdi Neijing (in Chinese). Shenyang: Liaoning Ethnic Publishing House,1999 [李文. 黄帝内经. 沈阳: 辽宁民族出版社, 1999]

3 Shang Z Z. Notes on Medicine in "Fifty-two Patient Prescriptions" (in Chinese). Wuhu: Scientific Research Center of Wannan Medical College, 1985 [尚志钧. 《五十二病方》药物注释. 芜湖: 皖南医学院科研科, 1985]

4 Zhang Z J. Annotation of Shang Han Lun (in Chinese). Changsha: Hunan Science and Technology Press, 1982 [张仲景. 伤寒论校注. 长沙: 湖南 科学技术出版社, 1982]

5 He R. Annotation of Jinkui Yaolue (in Chinese). Beijing: People’s Medical Publishing House, 1990 [何任. 《金匮要略》校注. 北京: 人民卫生出 版社, 1990]

6 Huang L Q, Sun L Y, Zhang X B, et al. Brief introduction to progress of national census of Chinese medicine resources (pilot) (in Chinese). China J Chin Mater Med, 2017, 42: 4256-4261 [黄璐琦, 孙丽英, 张小波, 等. 全国中药资源普查(试点)工作进展情况简介. 中国中药杂志, 2017, 42: 4256-4261]

7 Jiang T X. Flora Dictionary (in Chinese). (Photocopy Edition). Volume I. Shanghai: Shanghai Literature \& Art Publishing House, 1998 [蒋廷锡. 草 木典. (影印版). 上册. 上海: 上海文艺出版社, 1998]

8 Compilation Committee of Chinese flora of the Chinese Academy of Sciences. Flora Reipublicae Popularis Sinicae (in Chinese). Beijing: Science Press, 1979. 67 [中国科学院中国植物志编辑委员会. 中国植物志. 北京: 科学出版社, 1979. 67]

9 Tang S W. Da guan Ben cao (in Chinese). Shang Z J collated. Hefei: Anhui Science \& Technology Press, 2002. 180-181 [唐慎微. 大观本草. 尚志 钧点校. 合肥: 安徽科学技术出版社, 2002. 180-181]

10 Liu M Q, Wang X Q, Chen S Q, et al. Histochemistry of Rehmannia glutinosa (in Chinese). J Chin Med Mater, 2013, 36: 1771-1773 [刘孟奇, 王 小巧, 陈随清, 等. 地黄的组织化学研究. 中药材, 2013, 36: 1771-1773]

11 Wu Z C, Luo G M, Huo Y C. Extraction, isolation and TLC quantification of secretions from Rehmannia glutinosa secretory cells (in Chinese). Chin J Pharm Anal (Suppl), 1998, 18: 248-250 [吴子超, 罗干明, 霍永昌. 地黄分泌细胞分泌物的提取、分离和薄层扫描定量. 药物分析杂志 (增刊), 1998, 18: 248-250]

12 Zhang B Y, Jiang Z Z, Wang Y F, et al. Analysis of chemical constituents in fresh, dried and prepared Rehmannniae Radix by UPLC/ESI-Q-TOF MS (in Chinese). Chin Trad Patent Med, 2016, 38: 1104-1108 [张波泳, 江振作, 王跃飞, 等. UPLC/ESI-Q-TOF MS法分析鲜地黄、生地黄、熟 地黄的化学成分. 中成药, 2016, 38: 1104-1108]

13 Meng X Y. Studies on chemistry composition, standard of quality and anti-senescence activities of Rehmannia chingii Li (in Chinese). Master Dissertation. Yinchuan: Ningxia Medical University, 2015 [蒙雄裕. 天目地黄化学成分、治疗标准及其抗衰老活性研究. 硕士学位论文. 银川: 宁夏医科大学, 2015]

14 Li S L, Song J Z, Qiao C F, et al. A novel strategy to rapidly explore potential chemical markers for the discrimination between raw and processed Radix Rehmanniae by UHPLC-TOFMS with multivariate statistical analysis. J Pharm Biomed Anal, 2010, 51: 812-823

15 Qi M, Xiong A, Li P, et al. Identification of acteoside and its major metabolites in rat urine by ultra-performance liquid chromatography combined with electrospray ionization quadrupole time-of-flight tandem mass spectrometry. J Chromatogr B, 2013, 940: 77-85

16 Zeng G, Xiao H, Liu J, et al. Identification of phenolic constituents in RadixSalvia miltiorrhizae by liquid chromatography/electrospray ionization mass spectrometry. Rapid Commun Mass Spectrom, 2006, 20: 499-506

17 Geng D D, Dong Q, Tan L, et al. On-line screening and identification of free adical scavenging compounds in Salvia miltiorrhiza Bunge and Salvia prattii Hemsl. by HPLC-DAD-ESI/MSn-DPPH (in Chinese). J Instrum Anal, 2015, 34: 314-320 [耿丹丹, 董琦, 谭亮, 等. HPLC-DAD-ESI/MSnDPPH在线篎选与鉴别丹参和康定鼠尾草中抗氧化活性成分. 分析测试学报, 2015, 34: 314-320]

18 Pharmacopoeia of the People's Republic of China. Pharmacopoeia Commission of the People's Republic of China (in Chinese). Beijing: China Medical Science Press, 2015. 124 [国家药典委员会. 中华人民共和国药典. 一部. 北京: 中国医药科技出版社, 2015. 124]

19 Kang T G. Authentication of traditional Chinese medicine (in Chinese). Beijing: China Press of Traditional Chinese Medicine, 2016. 152-153 [ 康 廷国. 中药鉴定学. 北京: 中国中医药出版社, 2016. 152-153]

$20 \mathrm{Hu} \mathrm{Z} \mathrm{H}$. The relationship between the structure, development and medicinal components of medicinal plants (in Chinese). Shanghai: Shanghai 
Science and Technology Press, 2014. 352-354 [胡正海. 药用植物的结构、发育与药用成分的关系. 上海: 上海科学技术出版社, 2014. 352354]

21 Cheng Y L, Mei L T, Kuo H T. Effect of amylose content on the rheological property of rice starch. Cereal Chem, 1996, 73: 415-420

22 Ban G. History of the Han Dynasty (in Chinese). Beijing: Chinese Publishing House, 2016 [班固. 汉书. 北京: 中华书局, 2016]

23 Xu S. Origin of Chinese Characters (in Chinese). Beijing: Chinese Publishing House, 1985 [许慎. 说文解字. 北京: 中华书局, 1985]

24 Unknown. Plain Questions of Yellow Emperor's Canon of Medicine (in Chinese). Beijing: China Medical Science and Technology Press, 2018 [佚 名. 黄帝内经·素问. 北京: 中国医药科技出版社, 2018]

25 Sun X Y. The Shen Nong Ben Cao Jin (in Chinese). Beijing: People’s Medical Publishing House,1963. 13 [孙星衍辑. 神农本草经. 北京: 人民卫 生出版社, 1963. 13]

26 Lei X. Lei Gong Pao Zhi Lun (in Chinese). Hefei: Anhui Science and Technology Publishing House, 1991. 24 [雷敩. 雷公炮多论. 合肥: 安徽科学 技术出版社, 1991. 24]

27 Jiangxi Institute of Archaeology, Nanchang museum, Nanchang Xinjian District museum. Haihunhou Han Tomb (in Chinese). Archaeol, 2016, (7): 45-62 [江西省文物考古研究所, 南昌市博物馆, 南昌市新建区博物馆. 南昌市西汉海昏侯墓. 考古, 2016, (7): 45-62]

28 Ji Q L. The History of Sucrose (in Chinese). Beijing: China Customs Publishing House, 2009 [季羡林. 蔗糖史. 北京: 中国海关出版社, 2009]

29 Zhang L. A Variorum of Prescriptions of Fifty-two Diseases of Mawangdui Han Tomb (in Chinese). Beijing: Ancient Books Publishing House of Traditional Chinese Medicine, 2017 [张雷. 马王堆汉墓帛书《五十二病方》集注. 北京: 中医古籍出版社, 2017]

30 Zhang Z J. Typhus Various Illnesses to Discuss (Guilin Guben) (in Chinese). Beijing: China Press of Traditional Chinese Medicine, 2014 [张仲景. 伤寒杂病论 (桂林古本). 北京: 中国中医药出版社, 2014]

31 Li S Z. Compendium of Materia Medica (in Chinese). Volume I. Beijing: Huaxia Publishing House, 1998. 706 [李时珍. 本草纲目. 上册. 北京: 华 夏出版社, 1998. 706] 


\title{
The earliest excipient products of Traditional Chinese Medicine: Identification and analysis of samples from wooden lacquer box unearthed from Haihunhou tomb in the Western Han Dynasty
}

\author{
Huasheng Peng ${ }^{1,2 \dagger}$, Changqing $\mathrm{Xu}^{3 \dagger}$, Yuan Yuan ${ }^{2 \dagger}$, Liangping Zha ${ }^{1}$, Huanwen $\mathrm{Chen}^{4}$, Li Guan ${ }^{3}$, \\ Liping Kang ${ }^{2}$, Jun Yang ${ }^{3}$, Yajun Wang ${ }^{2}$, Lijuan Cao ${ }^{5}$, Jing Cheng ${ }^{6} \&$ Luqi Huang ${ }^{2 *}$ \\ ${ }^{1}$ School of Pharmacy, Anhui University of Traditional Chinese Medicine, Hefei 230012, China; \\ ${ }^{2}$ State Key Laboratory of Dao-di Herbs, National Resource Center for Chinese Materia Medica, China Academy of Chinese Medical Sciences, Beijing \\ 100700, China; \\ 3 Jiangxi Provincial Institute of Cultural Relics and Archaeology, Nanchang 330000, China; \\ ${ }_{5}^{4}$ Jiangxi Key Laboratory for Mass Spectrometry and Instrumentation, East China University of Technology, Nanchang 330000, China; \\ ${ }^{5}$ Institute of China History of Medicine and Medical Literature, China Academy of Chinese Medical Sciences, Beijing 100700, China; \\ ${ }^{6}$ Medical Systems Biology Research Center, School of Medicine, Tsinghua University, Beijing 100084, China \\ $\dagger$ Equally contributed to this work \\ *Corresponding author, E-mail: huangluqi01@126.com
}

The processing of traditional Chinese medicine is an integral part of Chinese medical heritage. The recent discovery of the earliest processed drugs may provide strong evidence for the origins of traditional Chinese medicine processing. The remains were found in wooden lacquer boxes, unearthed from Haihunhou tomb in Nanchang, Jiangxi Province. By analyzing the appearance of the unearthed samples, it was found that the outer layers of the samples were composed of an auxiliary material and the inside was composed of plant material. As can be seen from the three-dimensional image taken using nuclear magnetic resonance screening, the sample had a hollow irregular rod structure. The outer layers were composed of a substance with weak signal strength, and the inside was similar to the fiber structure of plants with high water contents. Microscopic analysis showed that periderm, secondary xylem, and broad wood rays could be seen in the transverse section of the plants inside the samples. It can be further speculated that the plants inside the samples were derived from the roots or stems of dicotyledonous herbs. Additionally, the putative roots or stems of the dicotyledonous herbs had secondary structures and contained one to three clustered, red-brown cells. No starch granules, calcium oxalate crystals, or stone cells were observed in the transverse section. According to the microscopic database of the National Resource Center for Chinese Materia Medica, China Academy of Chinese Medical Sciences, it is speculated that the plants inside the samples were derived from the roots of Rehmannia species. A comparative study of the microscopic characteristics of wild Rehmannia chingii roots and the unearthed samples was carried out. It was found that both displayed periderm, broad secondary phloem, wood rays, similar vessel morphologies, and red-brown cells. The unearthed samples and $R$. chingii roots were analyzed by electrospray ionization mass spectrometry (ESI-MS) in negative ion mode. The results showed that the mass spectrum peak of $\mathrm{m} / z 623$ in the unearthed samples agreed with that in the roots of $R$. chingii, and was putatively identified as acteoside or forsythiaside. Moreover, the peak at $m / z 179$ in the unearthed samples was identified as caffeic acid based on the molecular weight using high resolution tandem mass spectrometry (MS/MS) data, and was usually identified as a hydrolysate of acteoside or forsythiaside. There were about two to three outer layers of excipient on the samples. They were distributed unevenly, thicker at the top and thinner at the bottom. The plants and excipient layers were observed by microscope, and starch grains were found in the cross section and powder of the excipient layers, while no starch grains were found in the cross section or powder of the plant material inside. However, the reaction between the plant tissues and iodine-potassium iodide test solution produced the characteristic blue color. This phenomenon was related to the gelatinization of starch granules. Under a polarized light microscope, a large number of crystals were seen in the excipient layers. An aqueous extract of the excipient layers was analyzed by ultra-high performance liquid chromatography-quadrupole time-of-flight mass spectrometry (UPLC-QTOFMS), and an ion fragment peak at $\mathrm{m} / \mathrm{z} 341.11$ was detected, indicating a disaccharide. When compared to the reference substances glucose, sucrose, fructose, and maltose, the retention times and mass spectra were very similar to that of sucrose. According to ancient literary and historical records, the tomb owner suffered from severe rheumatism before his death, which is consistent with the efficacy of $R$. chingii. It is further speculated that the samples in the wooden lacquer boxes are the remains of processed ancient traditional Chinese medicine products. The origin of the excipients in the processed medicines might be related to improving the taste, which could provide a scientific basis for further understanding the processing and application of ancient traditional Chinese medicines.

Haihunhou Han tomb sites, Chinese materia medica processing, excipients, sucrose

doi: 10.1360/N972018-01176 